\section{The Role of the Fetal MRI to Predict the Postnatal Survival in Fetuses with Congenital Diaphragmatic Hernia}

\author{
Konjenital Diyafragma Hernili Fetüslerde Doğum \\ Sonrası Sağkalımı Tahmin Etmede Fetal MRG'nin \\ Rolü
}

\section{Fatma Ceren Sarıoğlu $\odot$ Orkun Sarıoğlu $\odot$ İnci Türkan Yılmaz ๑ Bahar Konuralp Atakul ๑ Deniz Öztekin $\odot$ Özgür Öztekin $\odot$}

ABSTRACT

Objective: To assess the role of the magnetic resonance imaging (MRI) to predict the postnatal survival in patients with congenital diaphragmatic hernia $(C D H)$.

Method: 25 patients with CDH who had fetal MRI between 2015 and 2020 were enrolled in this retrospective study. Patients were divided into two groups according to the postnatal survival at 30 days of age: alive and dead. The fetal MRI images were assessed to calculate the lung-to-liver signal intensity ratio (LLSIR), and the total lung volume (TLV). In addition, the site of the defect (right or left), accompanying liver herniation (present or absent), detectable-ipsilateral lung parenchyma at the apex (present or absent) were also recorded. MRI images were evaluated by two pediatric radiologists. A $p$ value lesser than 0.05 was considered statistically significant.

Results: Among 25 fetuses, 6 were alive and 19 were dead within 30 days after birth. The detectable lung parenchyma had a relationship with the alive group $(p=0.023)$. Observed-to-expected $\operatorname{TLV}(p=0.001)$ and $\operatorname{LLSIR}(p=0.023)$ were significantly lower in the dead group. Using the cutoff values for the observed-toexpected TLV as 0.27 (a sensitivity of 84\%, a specificity of 84\%) and for the LLSIR as 2.02 (a sensitivity of $89 \%$, a specificity of $67 \%$ ) were found as predictors for death.

Conclusion: The postnatal survival in CDH may be predicted using the observed-to-expected TLV and LLSIR on the fetal MRI. The presence of the detectable-ipsilateral lung parenchyma at the apex may also be associated with the postnatal survival.

Keywords: congenital diaphragmatic hernia, fetal, magnetic resonance imaging, prognosis, total lung volume

Öz

Amaç: Çalışmamızın amacı konjenital diyafragma hernisi (KDH) olan hastalarda fetal manyetik rezonans görüntüleme (MRG)'nin doğum sonrası sağ kalımı öngörmedeki rolünü değerlendirmektir.

Yöntem: Çalışmaya 2015 ile 2020 yılları arasında KDH ön tanısıyla fetal MRG ile değerlendirilmiş olan 25 $K D H$ hastası dahil edildi. Hastalar postnatal 30 günlük dönemde sağkalıma göre yaşayan ve yaşamayan olmak üzere iki gruba ayrıldı. Fetal MRG görüntüleri, akciğer-karaciğer sinyal yoğunluğu oranını ve total akciğer volümünü (TAV) hesaplamak için geriye dönük olarak değerlendirildi. Ek olarak, herni tarafı (sağ veya sol), eşlik eden karaciğer herniasyonu (var veya yok), herni tarafı ile ipsilateral apekste tespit edilebilir akciğer parankimi (var veya yok) kaydedildi. MRG görüntüleri iki pediatrik radyolog tarafından değerlendirildi. Prognozu tahmin etmek için duyarlıık-özgüllük analizleri kullanıldı. P değerinin <0.05 olması istatistiksel olarak anlamlı kabul edildi.

Bulgular: Postnatal 30 günlük dönemde 25 fetüsten 6'sı yaşayan ve 19'u ise yaşamayan gruptaydı. Herni tarafı ile ipsilateral apekste tespit edilebilir akciğer parankimi varlığı ile hastaların sağ kalımı arasında anlamlı ilişki saptandı ( $p=0.023)$. Yaşamayan grupta Gözlenen/beklenen TAV ( $p=0.001)$ ve akciğerkaraciğer sinyal yoğunluğu oranı ( $p=0.023$ ) anlamlı olarak daha düşüktü. Gözlenen/beklenen TAV'nin $<0.27$ olması \% 84 duyarlılık, \% 84 özgüllük ve AKSO değerinin <2.02 olması \% 89 duyarlılık, \% 67 özgüllük postnatal ölümü öngörücü olarak bulundu.

Sonuç: Sonuçlarımıza göre KDH'de postnatal sağkalım, fetal MRG'de gözlenen/beklenen TAV ve akciğerkaraciğer sinyal yoğunluğu oranı kullanılarak tahmin edilebilir. Ipsilateral apekste tespit edilebilir akciğer parankiminin varlığı doğum sonrası hayatta kalma ile ilişkilendirilebilir.

Anahtar kelimeler: konjenital diyafragma hernisi, fetal, manyetik rezonans görüntüleme, prognoz, total akciğer hacmi
Received: 24.02 .2021

Accepted: 11.03 .2021

Published Online: 03.08.2021

Cite as: Sarıoğlu FC, Sarıoğlu O, Yılmaz iT, Konuralp Atakul B, Öztekin D, Öztekin Ö. The role of the fetal MRI to predict the postnatal survival in fetuses with congenital diaphragmatic hernia. İzmir Dr. Behçet Uz Çocuk Hast. Dergisi. 2021;11(2):153-8.

Fatma Ceren Sarıoglu İzmir Sağlık Bilimleri Üniversitesi, Tepecik Eğitim ve Araştırma Hastanesi, Radyoloji Kliniği, Pediatrik Radyoloji Bölümü, İzmir, Türkiye - drcerenunal@gmail.com ORCID: 0000-0002-6714-2367

O. Sarıoğlu 0000-0003-1173-8046 İmir Demokrasi Üniversitesi

Tıp Fakültesi, Buca Seyfi Demirsoy

Eğitim ve Araştırma Hastanesi, Radyoloji Anabilim Dalı, İzmir, Türkiye

i.T. Yılmaz 0000-0001-8493-4043 İzmir Sağlık Bilimleri Üniversitesi, Tepecik Eğitim ve Araştırma Hastanesi, Radyoloji Kliniği, Pediatrik Radyoloji Bölümü, İzmir, Türkiye

B.K. Atakul 0000-0002-5550-6856 Balıkesir Atatürk Şehir Hastanesi, Kadın Hastalıkları ve Doğum Kliniği, Balıkesir, Türkiye

D. Öztekin 0000-0002-4213-7254 Izmir Bakırçay Üniversitesi Tıp Fakültesi, Çiğli Eğitim ve Araştırma Hastanesi, Kadın Hastalıkları ve Doğum Anabilim Dalı, İzmir, Türkiye

Ö. Öztekin 0000-0002-0092-5260 izmir Bakırçay Üniversitesi Tıp Fakültesi, Çiğli Eğitim ve Araştırma Hastanesi, Radyoloji Anabilim Dalı, Izmir, Türkiye 


\section{INTRODUCTION}

Congenital diaphragmatic hernia $(\mathrm{CDH})$, which has a frequency of almost 1 in 2500 live births, is a severe anomaly that has the potential for mortality and morbidity ${ }^{(1,2)}$. Abdominal organs displace to the thoracic cavity by a defect in the diaphragm. Many important lung diseases like abnormal lung development, pulmonary hypoplasia, and pulmonary hypertension may occur due to the compression of the lungs ${ }^{(3-5)}$. The significative factors for the mortality in $\mathrm{CDH}$ are noted as the grade of pulmonary hypoplasia and the presence of incurable pulmonary hypertension ${ }^{(6)}$.

Imaging has an essential role to evaluate the lung antenatally to estimate the prognosis and to decide the follow-up strategy. Although ultrasound plays an important role in the diagnosis of the $\mathrm{CDH}$, it may give limited information due to many maternal, fetal, and technical factors. However, magnetic resonance imaging (MRI) provides more accurate and detailed information about fetal anatomy, as it is known. MRI has been considered as a potential method for identifying prognostic factors associated with the degree of pulmonary hypoplasia ${ }^{(2,7)}$. Many centers have adopted using the fetal total lung volume (TLV) which is calculated on $\mathrm{MRI}$ to determine the degree of pulmonary hypoplasia in $\mathrm{CDH}^{\left({ }^{9-12)}\right.}$. Besides, the lung-to-liver signal intensity ratio (LLSIR) ${ }^{(13)}$, lung-to-spinal fluid signal intensity ratio ${ }^{(14)}$, and liver position on MRI were also investigated to estimate the fetal prognosis in $\mathrm{CDH}$.

The aim of this study was to assess the role of the fetal MRI to predict the prognosis in patients with $\mathrm{CDH}$. For this purpose, the diagnostic performances of the LLSIR and TLV, as well as the qualitative MRI features were taken into consideration.

\section{MATERIALS and METHODS}

\section{Patient selection}

This study was approved by our institutional review board. Our radiology and obstetrics and gynecology archives were retrospectively reviewed to determine the fetuses who had been diagnosed with $\mathrm{CDH}$ by antenatal ultrasound and evaluated by fetal MRI between January 2015-December 2020.
Two patients with motion artifacts on T2-weighted Half Fourier single-shot turbo spin-echo (HASTE) sequences were excluded. After the exclusion, 25 patients with $\mathrm{CDH}$ were enrolled in this study. Patients were divided into two groups according to the postnatal survival at 30 days of age: alive and dead. The alive group was defined for patients who lived after postnatal 30 days and the dead group was defined for patients who were not survived. The same management strategy was performed for all neonates after birth. Neonates were transferred to our neonatal intensive care unit after intubated nasally in the delivery room. Treatment strategies were performed according to the respiratory and hemodynamic issues. Surgical repair was performed on patients whose respiratory and hemodynamic conditions were stable.

\section{MRI protocols}

All examinations were performed on a 1.5-T MRI scanner (Siemens Aera, Germany). No maternal sedation was administered. Mothers were placed in the supine position. A torso phased array coil was wrapped around the mother's pelvis, centered at the area of the fetus. The MRI protocol included T2-weighted HASTE sequences in three orthogonal planes of the head and the body. For more details, true fast imaging with steady-state free precession, dixon T1-weighted and echoplanar sequences were also added in some of the patients. HASTE sequences of the fetal body were provided with no overlap or gap. HASTE sequence was acquired with the following parameters: HASTE sequence was acquired with the following parameters: time to repetition/time to echo, 1100/122 ms; slice thickness, 4-5 mm; field of view (FOV), 300-400 mm; matrix, 256×256; flip angle, 180; number of excitations, 1.

\section{MRI interpretation}

MRI images were evaluated by two pediatric radiologists in consensus. The site of the defect (right or left), accompanying liver herniation (present or absent), detectable-ipsilateral lung parenchyma at the apex (present or absent) were recorded (Figure 1). The LLSIR was calculated on T2-weighted HASTE 


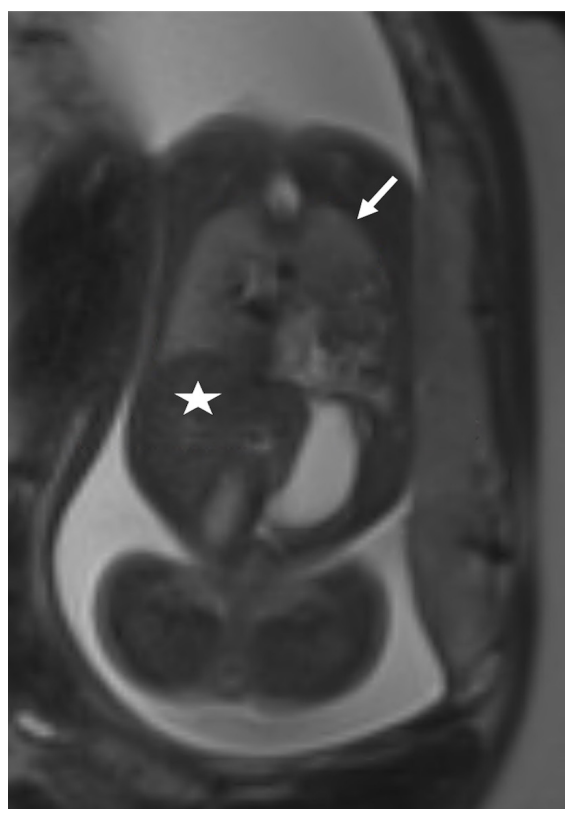

Figure 1. A 26-gestational week- fetus with left side herniation. A detectable-ipsilateral lung parenchyma at the apex was seen (arrow). Liver was in normal position (star).

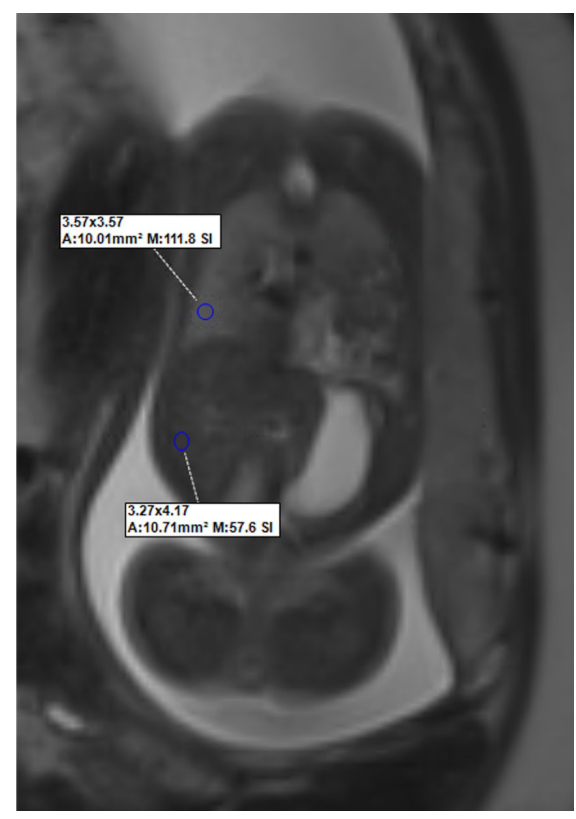

Figure 2. The calculation of the LLSIR. The ROls are placed at the homogeneous zones of the lung parenchyma and the liver. LLSIR: Lung-to-liver signal intensity ratio, ROI: Region-of-interest.

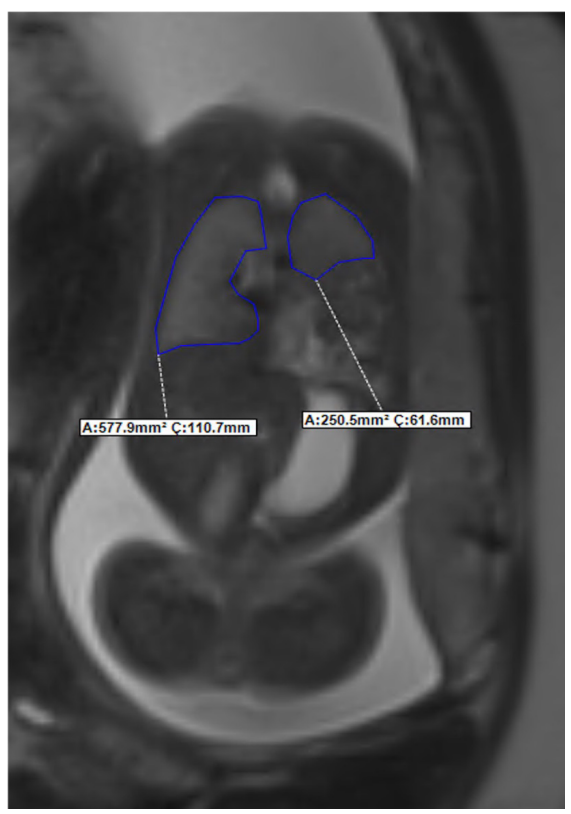

Figure 3. The measurement of the total lung volume. The freehand ROI on each contiguous slice was delineated to provide the lung area. coronal sequences. The signal intensities of the lung and liver were obtained from the same section to avoid the signal changes on the different slices. The lung parenchyma signal intensity was measured on the homogeneous zone of the contralateral lung parenchyma according to the herniation site by a single region-of-interest (ROI). The portal vein and major branches were not included to the ROI when measuring the liver parenchyma signal intensity (Figure 2). Sizes of the ROIs were manually adjusted as approximately $1 \mathrm{~cm}^{2}$.

For the calculation of the TLV, axial and coronal planes on HASTE sequences were used separately. First, the lung area was calculated using the freehand $\mathrm{ROI}$ on each contiguous slice to provide a sum of cross-sectional areas (in $\mathrm{mm}^{2}$ ). Then, the total lung area was multiplied by slice thickness (in $\mathrm{mm}$ ) to provide a volume (in $\mathrm{mm}^{3}$ ) ${ }^{(15)}$. Subsequently, the TLV measured in axial and coronal planes was averaged to obtain the mean observed TLV (Figure 3). The observed-to-expected TLV was calculated by dividing the observed TLV by the expected TLV of a gestational age-matched healthy fetus. In our study, we considered the expected TLV values provided by Meyers et al. ${ }^{(16)}$ that were provided from a large cohort.

\section{Statistical analysis}

Statistical analyses were done using IBM SPSS ver. 22.0 (IBM Corp.). Categorical variables were summarized with frequency counts and percentages and the continuous features were summarized with means and standard deviations. Continuous variables were compared by the Mann-Whitney $U$ test. Chi-square and Fisher's exact tests were performed to analyze the association between the categorical variables and prognosis. Receiver operating characteristic (ROC) curve analyses were performed for each statistically significant parameter to evaluate the ability to predict the prognosis. A $p$-value lesser than 0.05 was considered as statistically significant.

\section{RESULTS}

Twenty-five patients were included in this study. The mean gestational week at the fetal MRI was 
Table 1. The patients' characteristics.

\begin{tabular}{lccc}
\hline & $\begin{array}{c}\text { Ssurvived } \\
\text { group } \\
\text { (n=6) }\end{array}$ & $\begin{array}{c}\text { Non-survived } \\
\text { group } \\
(\mathbf{n}=\mathbf{1 9})\end{array}$ & $\begin{array}{c}\mathbf{p} \\
\text { value }\end{array}$ \\
\hline Gestational week at fetal MRI & $26.17 \pm 7,2$ & $24.74 \pm 5.3$ & 0.733 \\
Maternal age & $24.33 \pm 2.5$ & $28.47 \pm 5.8$ & 0.138 \\
Birth weight* & $2935.0 \pm 538.5$ & $2736 \pm 553.5$ & 0.319 \\
Apgar score at 1 minutes* & $5.67 \pm 2.3$ & $3 \pm 1.4$ & 0.010 \\
\hline
\end{tabular}

MRI: Magnetic resonance imaging

* Birth weight and Apgar score were calculated in 23 fetuses because of the terminations of the two pregnancies.

$25.08 \pm 1.1$ (18-36). Among 25 fetuses, 6 were alive and 19 were dead within 30 days after birth. The demographic characteristics of the patients were shown in Table 1. Two pregnancies underwent termination in terms of the parents' decision and these fetuses were classified under the dead group. Apgar score at 1 minute was significantly lower in the dead group $(p=0.010)$.

The MRI features were shown in Table 2. The left side herniation (23 of 25 patients) was dominant in both groups ( $83.3 \%$ of the alive group and $94.7 \%$ of the dead group). 14 of 25 patients had liver herniation and among them, 12 patients had left liver lobe herniation due to the left-sided diaphragmatic defect. The detectable lung parenchyma was found in $83.3 \%$ of the alive group $(p=0.023)$.

The observed-to-expected TLV values were significantly lower in the dead group $(0.42 \pm 0.12$; $0.20 \pm 0.09, p=0.001)$. The LLSIR values were also found lower in the dead group $(2.31 \pm 0.79 ; 1.7 \pm 0.31$, $p=0.025)$. The ROC curve analysis showed that the observed-to-expected TLV had a larger area under the curve (0.930) than LLSIR (0.807) to predict death. Using the cutoff value for the observed-to-expected TLV as 0.27 had a sensitivity of $84 \%$ and a specificity of $84 \%$ for predicting death in fetuses with $\mathrm{CDH}$. The optimal cutoff value for the LLSIR was 2.02, with a sensitivity of $89 \%$ and a specificity of $67 \%$ for death within 30 days after birth.

\section{DISCUSSION}

We evaluated the role of the fetal MRI to estimate the postnatal survival in $\mathrm{CDH}$. According to our results, the observed-to-expected TLV and LLSIR may help to predict the postnatal survival. An observedto-expected TLV value lower than 0.27 and an LLSIR value lower than 2.02 were the significant predictors for death within 30 days after birth. In addition, the detectable lung parenchyma on the ipsilateral side was associated with survival.

MRI allows more accurate information about fetal TLV since it is not limited by a fetal lie or maternal body habitus ${ }^{(9,11)}$. Different methods can be used for the measurement of the fetal TLV on MRI. The lung parenchyma can be outlined on each slice by the freehand ROI and multiplied by the slice thickness ${ }^{(7,16)}$. Moreover, the sequences can be exported to a 3-D workstation for segmentation and can be measured by manual or automated delineation of ROI ${ }^{(16)}$. Fetal TLV is also estimated by subtracting the mediastinal volume from the total thoracic volume ${ }^{(12)}$. The formulas for the prediction of expected fetal TLVs adjusted for gestational age (GA) by MRI measurements have been provided by Rypens

Table 2. Magnetic resonance imaging findings.

\begin{tabular}{|c|c|c|c|}
\hline & $\begin{array}{l}\text { Ssurvived group } \\
(n=6)\end{array}$ & $\begin{array}{l}\text { Non-survived group } \\
\qquad(\mathrm{n}=19)\end{array}$ & p value \\
\hline Herniation site (Right/left) & $1 / 5$ & $1 / 18$ & 0.430 \\
\hline Presence of the liver herniation & $3(50 \%)$ & $11(57.9 \%)$ & 1.000 \\
\hline Presence of the detectable lung parenchyma & $5(83.3 \%)$ & $5(26.3 \%)$ & 0.023 \\
\hline TLV & $18961.6 \pm 19110.3$ & $7422.68 \pm 6381.2$ & 0.069 \\
\hline Observed-to-expected TLV & $0.42 \pm 0.12$ & $0.20 \pm 0.09$ & 0.001 \\
\hline Lung signal intensity & $329.5 \pm 113.2$ & $282.7 \pm 175.8$ & 0.598 \\
\hline Liver signal intensity & $147.6 \pm 57.3$ & $166.7 \pm 104.0$ & 0.733 \\
\hline LLSIR & $2.31 \pm 0.79$ & $1.7 \pm 0.31$ & 0.025 \\
\hline
\end{tabular}

TLV: Total lung volume, LLSIR: lung-to-liver signal intensity ratio 
et al. ${ }^{(7)}$ and Meyers et al. ${ }^{(16)}$ as follows:

According to Rypens et al. (7) (2001): $\mathrm{TLV}=0.0033 \times(\mathrm{GA})^{2.86}$, in 2001. Recently, Meyers et al

${ }^{(16)}$ suggested a formula according to a larger cohort of fetuses with gestational ages ranging from 18 to 38 weeks as follows: $T L V=0.000865 \times(G A)^{3.254}$. In cases of pulmonary hypoplasia, observed-to-expected fetal TLV should be used regardless of the measuring method of the TLV.

Cannie et al. ${ }^{(17)}$ showed that the observed-toexpected TLV was an independent predictor of postnatal survival in $\mathrm{CDH}$ patients. They showed that fetuses with $\mathrm{CDH}$ who had $25 \%$ of expected TLV had a survival rate of $25 \%$. Barnewalt et al. ${ }^{(12)}$ demonstrated that patients with observed-to-expected TLV ratio of less than $15 \%$ had a higher risk for mortality in their small study population. Our results were compatible with the literature. We found that patients who could not survive had an observed-to-expected TLV ratios of lower than 0.27. In other words, the TLV less than approximately $25 \%$ of expected value was associated with high mortality.

There have been several studies that assessed fetal lung maturity by using LLSIR ${ }^{(18-20)}$. Brewerton et al. ${ }^{(18)}$ showed that the LLSIR ranged from 1.52 to 4.31 between 21st and 34th gestational weeks. Moshiri et al. ${ }^{(19)}$ manifested a normal mean value of LLSIR as 2.5. Oka et al. ${ }^{(20)}$, found that a cut-off value of $\leq 2.0$ for LLSIR was a good indicator for predicting respiratory outcome after birth. These studies have demonstrated that the fetal LLSIR increases with gestational age. The investigators thought that higher LLSIR values could be related to fluid accumulation in the lungs during fetal lung development with increasing gestational age.

Contralateral lung maturity evaluated with the LLSIR provided important prognostic information. Yamato et al. (21) investigated the LLSIR in the unaffected contralateral lungs of patients with isolated left-sided $\mathrm{CDH}$ detected on MRI. They observed that the LLSIR increased in parallel with advanced gestational age in the healthy control group but did not in the $\mathrm{CDH}$ group with good or bad prognosis. They suggested cut-off values of 2.16, and 2.22 with the aim to identify the fetuses in the early and late stages of $\mathrm{CDH}$ with good or bad prognosis. Our results were compatible with the literature.

We also examined the association between the detectable lung parenchyma in the herniation side and survival. We showed a relationship between the presence of a detectable lung parenchyma on the ipsilateral side and survival. We thought that this finding may help to predict the survival along with other specific parameters. Yokoi et al. ${ }^{(22)}$ proposed a risk stratification using both the detectable lung parenchyma at the apex and the contralateral LLSIR with a cut-off value of 2 on MRI. They reported that all fetuses with detectable lung parenchyma had survived.

Although liver herniation is accepted as a prognostic factor for survival and severity of the pulmonary hypoplasia by many authorities, there have been controversial results in the literature. Ruano et al. ${ }^{(23)}$ could not demonstrate any significant association between either the mortality or the need for ECMO and liver herniation. Nevertheless, they found significant differences in the amount of the liver harniation between the groups with good and bad prognosis. In our study, there was no significant relationship between liver herniation and survival. We considered the liver herniation as a dichotomous variable (either absent or present) and did not use it in the quantification of liver herniation. This may be the reason for this incompatibility.

Our study had several limitations. Firstly, the study had a retrospective design, and the number of our patient population was rather small. Secondly, we did not use three-dimensional MRI sequences for volumetric analysis since they were not performed routinely due to the long acquisition time in fetal MRI. Although we used the same method with the literature, three-dimensional MRI sequences might provide more accurate results. Thirdly, the interpretation of the MRI findings was performed by two pediatric radiologists in consensus which might limit to reproducibility of our results. Fourthly, morbidities were not considered in this study, and we grouped the patients as survived and nonsurvived cases. We did not evaluate other outcome parameters due to the insufficient information about patients in our archives. 


\section{CONCLUSION}

In conclusion, fetal MRI is an important tool for evaluating patients with $\mathrm{CDH}$. Based on our results, we established that the postnatal survival in $\mathrm{CDH}$ may be predicted using the observed-to-expected TLV and LLSIR on the fetal MRI. The presence of the detectable-ipsilateral lung parenchyma at the apex may also be associated with the postnatal survival. To achieve more definitive results of the prognostic value of the fetal MRI, more studies including larger numbers of patients are needed.

Ethics Committee Approval: SBU. Approval was obtained from the Tepecik Training and Research Hospital Clinical Research Ethics Committee (2021/01-17). Conflict of Interest: The authors declare that they have no conflict of interests.

\section{Funding: None.}

Informed Consent: Written informed consent was waived by the Institutional Review Board.

\section{REFERENCES}

1. Langham MR Jr, Kays DW, Ledbetter DJ, Frentzen B, Sanford LL, Richards DS. Congenital diaphragmatic hernia. Epidemiology and outcome. Clin Perinatol. 1996;23(4):671-88.

https://doi.org/10.1016/S0095-5108(18)30201-X

2. Kastenholz KE, Weis M, Hagelstein $C$, et al. Correlation of observed-to-expected MRI fetal lung volume and ultrasound lung-to-head ratio at different gestational times in fetuses with congenital diaphragmatic hernia. AJR Am J Roentgenol. 2016;206(4):856-66. https://doi.org/10.2214/AJR.15.15018

3. Bargy F, Beaudoin S, Barbet P. Fetal lung growth in congenital diaphragmatic hernia. Fetal Diagn Ther. 2006;21(1):39-44. https://doi.org/10.1159/000089046

4. Sokol J, Shimizu N, Bohn D, Doherty D, Ryan G, Hornberger LK. Fetal pulmonary artery diameter measurements as a predictor of morbidity in antenatally diagnosed congenital diaphragmatic hernia: a prospective study. Am J Obstet Gynecol. 2006;195(2):470-7.

https://doi.org/10.1016/j.ajog.2006.02.009

5. Peralta CF, Jani J, Cos T, Nicolaides KH, Deprest J. Left and right lung volumes in fetuses with diaphragmatic hernia. Ultrasound Obstet Gynecol. 2006;27(5):551-4. https://doi.org/10.1002/uog.2752

6. Nishie A, Tajima T, Asayama Y, et al. MR prediction of postnatal outcomes in left-sided congenital diaphragmatic hernia using right lung signal intensity: comparison with that using right lung volume. J Magn Reson Imaging. 2009;30(1):112-20. https://doi.org/10.1002/jmri.21829

7. Rypens F, Metens T, Rocourt N, et al. Fetal lung volume: estimation at MR imaging-initial results. Radiology 2001;219:236-41. https://doi.org/10.1148/radiology.219.1.r01ap18236

8. Victoria T, Danzer E, Adzick NS. Use of ultrasound and MRI for evaluation of lung volumes in fetuses with isolated left congenital diaphragmatic hernia. Semin Pediatr Surg. 2013;22:30-6. https://doi.org/10.1053/j.sempedsurg.2012.10.006
9. Jani JC, Cannie M, Peralta CF, Deprest JA, Nicolaides $\mathrm{KH}$, Dymarkowski $\mathrm{S}$. Lung volumes in fetuses with congenital diaphragmatic hernia: comparison of 3D US and MR imaging assessments. Radiology. 2007;244(2):575-82. https://doi.org/10.1148/radiol.2442061158

10. Jani J, Cannie M, Done E, et al. Relationship between lung area at ultrasound examination and lung volume assessment with magnetic resonance imaging in isolated congenital diaphragmatic hernia. Ultrasound Obstet Gynecol. 2007;30(6):855-60. https://doi.org/10.1002/uog.5168

11. Strizek B, Cos Sanchez T, Khalifé J, Jani J, Cannie M. Impact of operator experience on the variability of fetal lung volume estimation by 3D-ultrasound (VOCAL) and magnetic resonance imaging in fetuses with congenital diaphragmatic hernia. J Matern Fetal Neonatal Med. 2015;28(7):858-64. https://doi.org/10.3109/14767058.2014.935760

12. Barnewolt CE, Kunisaki SM, Fauza DO, et al. Percent predicted lung volumes as measured on fetal magnetic resonance imaging: a useful biometric parameter for risk stratification in congenital diaphragmatic hernia. J Pediatr Surg. 2007;42:193-7. https://doi.org/10.1016/j.jpedsurg.2006.09.018

13. Balassy C, Kasprian G, Brugger PC, et al. Assessment of lung development in isolated congenital diaphragmatic hernia using signal intensity ratios on fetal MR imaging. Eur Radiol. 2010;20(4):829-37. https://doi.org/10.1007/s00330-009-1633-x

14. Terui $\mathrm{K}$, Omoto $\mathrm{A}$, Osada $\mathrm{H}$, et al. Prediction of postnatal outcomes in congenital diaphragmatic hernia using MRI signal intensity of the fetal lung. J Perinatol. 2011;31(4):269-73. https://doi.org/10.1038/jp.2010.119

15. Mehollin-Ray AR, Cassady Cl, Cass DL, Olutoye OO. Fetal MR imaging of congenital diaphragmatic hernia. Radiographics. 2012;32(4):1067-84. https://doi.org/10.1148/rg.324115155

16. Meyers ML, Garcia JR, Blough KL, Zhang W, Cassady Cl, MehollinRay AR. Fetal Lung Volumes by MRI: Normal weekly values from 18 through 38 weeks' gestation. AJR Am J Roentgenol. 2018;211(2):432-8. https://doi.org/10.2214/AJR.17.19469

17. Cannie M, Jani J, Meersschaert J, et al. Prenatal prediction of survival in isolated diaphragmatic hernia using observed to expected total fetal lung volume determined by magnetic resonance imaging based on either gestational age or fetal body volume. Ultrasound Obstet Gynecol. 2008;32(5): 633-9. https://doi.org/10.1002/uog.6139

18. Brewerton LJ, Chari RS, Liang Y, Bhargava R. Fetal lung-to-liver signal intensity ratio at MR imaging: development of a normal scale and possible role in predicting pulmonary hypoplasia in utero. Radiology 2005;235:1005-10. https://doi.org/10.1148/radiol.2353040280

19. Moshiri M, Mannelli L, Richardson ML, Bhargava P, Dubinsky TJ. Fetal lung maturity assessment with MRI fetal lung-to-liver signal-intensity ratio. AJR Am J Roentgenol. 2013;201(6):138690. https://doi.org/10.2214/AJR.12.9679

20. Oka Y, Rahman M, Sasakura C, et al. Prenatal diagnosis of fetal respiratory function: evaluation of fetal lung maturity using lung-to-liver signal intensity ratio at magnetic resonance imaging. Prenat Diagn. 2014;34(13):1289-94.

https://doi.org/10.1002/pd.4469

21. Yamoto $M$, Iwazaki T, Takeuchi $K$, et al. The fetal lung-to-liver signal intensity ratio on magnetic resonance imaging as a predictor of outcomes from isolated congenital diaphragmatic hernia. Pediatr Surg Int. 2018;34(2):161-8. https://doi.org/10.1007/s00383-017-4184-2

22. Yokoi A, Ohfuji S, Yoshimoto S, Sugioka Y, Akasaka Y, Funakoshi T. A new approach to risk stratification using fetal MRI to predict outcomes in congenital diaphragmatic hernia: the preliminary retrospective single institutional study. Transl Pediatr. 2018;7(4):356-61. https://doi.org/10.21037/tp.2018.09.01

23. Ruano R, Lazar DA, Cass DL, et al. Fetal lung volume and quantification of liver herniation by magnetic resonance imaging in isolated congenital diaphragmatic hernia. Ultrasound Obstet Gynecol. 2014;43:662-9. https://doi.org/10.1002/uog.13223 